\title{
Is Women Empowerment a Zero-Sum Game? Unintended Consequences of Microfinance for Women's Empowerment in Pakistan
}

\author{
SALMAN ARSHAD ${ }^{1}$, AISHA IMTIAZ², SYED MUHAMMAD AHMAD HASSAN GILLANI ${ }^{3}$, \\ SHARINA OSMAN ${ }^{4}$ \\ ${ }^{1}$ Lyallpur Business School, GC UNIVERSITY FAISALABAD, PAKISTAN. \\ ${ }^{2}$ Department of Business Administration, GOVERNMENT COLLEGE WOMEN UNIVERSITY FAISALABAD, \\ PAKISTAN. \\ ${ }^{3}$ Lyallpur Business School, GC UNIVERSITY FAISALABAD, PAKISTAN. \\ ${ }^{4}$ Business School, UNIVERSITI KUALA LUMPUR, MALAYSIA. E-mail: sharina@unikl.edu.my
}

\begin{abstract}
Given that development initiatives could at from time to time, be a "zero-sum game", this study looks at the unforeseen effects of microfinance in Pakistan for females' "empowerment". In order to discover the complexities of the microfinance impact on females in societies with various disadvantages in Pakistan, the research uses a participation-based methodology involving household "questionnaires surveys, focus group discussions and major interviews." The effects of multiple regressions, median closure, and themes studies indicate that the financial effects of microfinance for women are often closely connected to disputes between spouses, child labour, heterosexual monogamy and the lack of supposed traditional women's duty due to their entrepreneurship. With limitations on scientific findings regarding the possible negative effects of females' "empowerment" in Pakistan, the study evaluated crucial research gaps, which will allow non-governmental organizations, policymakers and other stakeholders to design and execute better initiatives that minimize the adverse concerns.
\end{abstract}

Keywords: Microfinance; Women Empowerment, Unintended Consequences; Pakistan

JEL Classification: A13, B54, C12, G20, R51 


\section{Introduction}

Often implementation steps may have unforeseen and very substantial repercussions. Measures to fix or alleviate one issue may also lead to new issues or exacerbate those that occur. Using technical advances, for example, is traditionally an integral part of the company's strategy to increase its competitiveness and increase profitability. On the contrary, new technologies, which rely increasingly on automation and less on human labour, contribute to increased poverty and higher unemployment (Frey and Osborne, 2015; Sveiby et al., 2009). Likewise, policies intended to improve the life of slum residents are also used to explain the expulsions of slum residents and developments funded by the government (Meth, 2013). This prompted many professionals to articulate the worry that reform efforts could be a zero-sum game if not well-designed and applied carefully. If the benefit is lost in one region or, more importantly, is wasted in other regions.

Female "empowerment" development projects are one field of concern, particularly in sub-Saharan Cultures today. In the past 10 years, we have become more conscious of the adverse and unintended effect of measures to boost disadvantaged people's economic position on the wellbeing of women. For instance, whereas the female's economy can lead to poverty alleviation by growing female's financial power, it can also shift household power relations and contribute to a higher risk of sexual abuse by men who try to assert dominance (Asia, 2014, Khan et al. 2020).

Several researchers have concluded that female's microfinance will help reduce poverty and boost business growth "(Ogato, 2013; Salia, 2014; Srivinisa and Shivanna, 2014)." In this sense, Al Dajani and Marlow (2013) have noted that the "empowerment" of disadvantaged dependent females by their home-based companies. Entry into microfinance in Asia has shown that female "empowerment" selfgovernment and negotiation capacity is strengthened. However, the potential benefits are also restricted in the Asian patriarchal environment and impeded by it (Kulkarni, 2011).

\subsection{Research Gap}

In social-cultural environments where social norms are rigidly structured and financial "empowerment" for females interrupts gender-based standards through new models of conduct, the threat of sexual assault is extreme (Hughes et al., 2015). Particularly in the case of social inequality in Pakistan (Blackden et al., 2006) and the involvement in empowering female's initiatives toward reducing sex inequality, the vulnerability to unexpected impacts in empowering women programs must be taken cautiously. Unfortunately, these unintentional effects are illuminated by no empirical evidence. This study fills this important gap in knowledge.

\section{2. "Research Objectives"}

The main objectives of the research are:

- To discover the association among the "MFl's services" success for females "empowerment" on "poor family cohesion."

- To examine the "Microfinance" initiatives, pay to the request for "child labour" and influence undesirably on school appearance for girls.

- "To examine the level of recipient education positively moderates the relationship between poor family cohesion and MFI's services for women 's empowerment".

\subsection{Research Questions}

1. What is the association among the "MFl's services" success for females "empowerment" on "poor family cohesion"?

2. "How the Microfinance initiatives contribute to the demand for child labour and impact negatively on school attendance for girls"? 
3. How the "level of recipient education positively moderates the relationship between poor family cohesion and MFI's services for women's empowerment"?

\subsection{Contribution of the Study}

Likewise, females' failure to participate in family income in Pakistan is attributable to their more inferior monetary and cultural status in civilization "(Agyei et al., 2016)." Consequently, entry to microfinance will boost women personal and behavioural "empowerment" in terms of providing jobs "(Ganle et al., 2015; Seidu and Bambangi, 2006)." The subsequent effect of microfinance on family cohesion and wellbeing has therefore been provided little research interest.

For instance, women entrepreneurs are frequently discriminated against in gender-based discrimination (Zeidan and Bahrami, 2011). These interactions dissuade women from participating in undertakings. This research aims at the literary works of Microfinance to consider Pakistan unforeseen implications for empowering women, their family dynamics and their obstacles to microfinance and the general society.

\section{Literature Review}

\section{1. "Gender and Finance"}

The principle of empowering women is a societal communication structure (Stromquist, 2015). In recent times, researchers have discussed how males and females "do sex" and how they help create sexual orientation by participating in a balanced relationship that affects poverty (Darlington and Mulvaney, 2014). The mutual growth mechanism reduces severe poverty, according to Klugman et al. (2014). This opinion toward the connection among the "empowerment" of women besides "poverty", which have consequences for the idea of "empowerment" of women. There is a disparity between existence and type of poverty (García Rodríguez, 2012). Therefore, ineffectiveness, lack of representation and independence are the apt basis for defining poverty (Lang, 2011).

MFIs will boost the mutual status of women in gender by enabling them to resolve the finance gap. Blattman et al. (2013) noted that access to financial services by MFIs could speed up the economic tempo of companies' women-owned. Detrimental consequences on family and social cohesion could also, by experiencing domestic violence, contradict woman accomplishment. Thus, this study pursues to check the hypothesis:

$\mathrm{H}_{1}$ : "There is a significantly positive relationship between the success of MFI's services for women`s empowerment and poor family cohesion".

Consistency requires parental besides feminine insulation and is regarded as an essential factor for the family's successful working (Jaggers et al. 2015; Jin, 2015). Friggeri et al. (2011) indicate that the model of cohesion is based on a devastating inference. A domain which specifies that provided 3 points $\curlyvee X \Phi$, where there is a close relationship among $\Upsilon-X, \gamma-\Phi$ (Opsahl, 2013). For instance, $X-\Phi$. Conflict relating to microfinance; and $\Phi=$ weak family cohesion is suggested in the sense of this research to clarify these associations. Conducting this research, a correlation among conflict in microfinance and "poor family cohesion" can be expected, whether poor or fair, if the "negative trust (NT)" has a relationship by together "Microfinance Related Conflict (MRC)" and "poor family cohesion (COH)."

Domestic and societal consistency is a building for a vigorous collaborative effort linking a community of individuals via a principle of cooperation and social engagement (Peterson and Hughey, 2004). "It is an essence of balanced connections which prevent illnesses (see Falb et al., 2014; Fuligni and Tsai, 2015)." Family and community assistance build social capital, solidarity, and a beneficial impact on empowering women (Baiyegunhi, 2014; Milanov et al., 2015). The dynamics of social relations inside the family and the effect of position reversals from females have not received sufficient attention from the ongoing study (Mayoux, 2001). However, recent research has shown worry that women's micro-finance will exacerbate conflict and weaken women more (Silverberg, 2014) and 
negatively affect girls' welfare and education because of increased "child labour" demand. (Augsburg et al., 2012; Beaman et al., 2012). Thus, the study tests the hypothesis:

H2: Projects of microfinance lead to child labour needs and adversely affect girls' performance at school. Although more or less researches have proven that highly skilled females can produce superior results from MFIs and resolve or reduce potentially adverse effects (Augsburg et al., 2012; Leatherman et al., 2011). Besides, Raven and Le (2015) claimed that enabling women to earn microcredit in business would boost profitability and have other significant consequences. This study aims to discover whether women's education levels will reduce the family's unintentional poor cohesion emerging out of exposure to microfinance. The following hypothesis is tested.

H3: The extent of beneficiary learning moderates favourably the association between the 'poor family cohesion' and the 'empowerment' services offered by MFIs.

\section{2. "Cultural and Institutional Issues"}

Females frequently spend much of their time in homework, particularly in rural areas, with very few successful business possibilities. Their susceptibility to poverty is related to and typically aggravated by gender inequality (Awumbila, 2006). In acknowledgement of these issues, the UN announced, with its sustainable development goals (SDGs), that it is not feasible to realize the unlimited human capacity and sustainable development if half the world's population persists to be refused fundamental civil rights and full opportunity" (United Nations, 2015).

Ghana is effecting the economic participation of women and has adverse effects on the economy (Banerjeet al. 2013; Klugman et al. 2014), and the persistent financial gap and economic exclusion, as well as income distribution disparities, have shown that Ghana's financial institutions have no plans toward aiming female "entrepreneurs." Alternatively, "Maldonado and González Vega (2008)" stated that specific Microfinance programmes, which undermine family relations and have an adverse influence on the benefit of women, have adverse effects on child labour. In order to promote entrepreneurial adoption for women, it is therefore essential to examine the micro-finance influence on people in Ghana, inside the present cultural and behavioural parameters, whereas mitigating potential adverse effects.

\subsection{Women'S "Empowerment"}

Residential economies analyses show that gender differences in African families are attributable to poor power structures. Female have limited negotiating power because of their limited financial situation. Poverty-reduction microfinance strengthens the mind-set of women in Ghana, improving their trust and self-assurance to take part in decision-making processes in households or communities effectively "(Annim and Alnaa, 2013; Halkias et al., 2011)." On the other hand, the absence of financial assets and credit availability impairs business development in Africa (United Nation, 2010), which for women entrepreneurs is also higher (Goltz et al., 2015). Despite having provided over $80.0 \%$ of the food in "Sub-Saharan Africa", females have restricted credit availability (Jalbert, 2000).

Aggarwal et al. (2015) claim that female's debtors have a more substantial socioeconomic influence, but Ghana still has an adverse gender gap in access to funds. Women will join the business sector and make an immense contribution to Ghana's GDP growth. The high reliance of women on men's families undermines their business characteristics and negatively affects the family and financial health of women. Also, inefficiency and micro-finance costs hinder women's capacity to escape poverty (Schindler, 2010).

During the statement, despite the rationale for women's microfinance as a matter of course, a Focused Gender Microfinance Program frequently is far from being the direct approach of several microfinance institutions. Many research has said that in Africa, MFIs often recognize family leaders as a way of lending to people in the family for the growth of businesses "(Gobezie, 2009). In reality, the heads of families in Africa, who are frequently men, manage their women's assets (Tamale, 2004). This denial of access to finance prevents women from being independent by a business." Ghana's 
conventional family system, in which men rule the organization of their households, allows them to use capital as a way to manage the holiday. The lack of comprehensive institutional frameworks in Ghana contributes to more culturally specific social problems and provides an atmosphere that produces results that deprive women of influence.

\section{Research Methods}

\subsection{Sample and Population}

Thus, microfinance on family cohesion in Pakistan's benefiting families was analyzed by a mixedmethod approach. This research uses a cross-sectional quantitative analysis of a sample of 1000 selected female micro-enterprises in Pakistan. Constructed on primary focus group considerations and experimental questionnaires were created. The final questionnaire consists of three sections: (1) personal and family information, (2) measurable data using the Likert scale and semi-structured questions after pre-testing and final redesign. The third section included women who took loans 2, 3 and 4 years prior and were questioned for this research based on experience as a debt recipient. $A$ sample of 1,000 microenterprises has given a total of 264 valid answers, a response rate of $22 \%$ that measures up with comparative tests (see, for example; Alabi et al., 2007).

\subsection{Instruments}

In Table 1, a selection of variables is described to test the validity regarding the development of the association among "family cohesion, dependent variable and independent variables. Table 1 evidence suggests the values of Cronbach."

Table 1 Construct Reliability

\begin{tabular}{|c|c|}
\hline Variable & Cronbach's alpha \\
\hline MFS & 0.78 \\
\hline $\mathrm{COH}$ & 0.77 \\
\hline
\end{tabular}

Table 2: Variables and measurement.

\begin{tabular}{|c|c|}
\hline "Variable" & Measurement \\
\hline $\begin{array}{l}\mathrm{COH}=\text { "poor family } \\
\text { cohesion" }\end{array}$ & $\begin{array}{l}\text { "poor family cohesion is measured by three items (3): (a) spousal disputes, (b) } \\
\text { polygyny practice and (c) perceived neglect of female domestic responsibilities. In } \\
\text { the questionnaire, respondents were asked to tick whether they agree or disagree } \\
\text { that access to and use of MFI services for women`s empowerment result in each of } \\
\text { the three measured outcome variables for poor family cohesion. We anchored each } \\
\text { of these responses on a five-point Likert scales of } 1 \text { strongly disagree and } 5 \text { strongly } \\
\text { agree in accordance with the guidelines by" Raaijmakers et al. (2009). }\end{array}$ \\
\hline \multicolumn{2}{|l|}{ "Independent Variable" } \\
\hline $\begin{array}{c}\text { "MFS = Microfinance } \\
\text { Services" }\end{array}$ & $\begin{array}{c}\text { "Microfinance Services is measured by the four main services provided by } \\
\text { Microfinance institutions (training, social capital, savings and credit). This was } \\
\text { measured on a five -point scale with anchors ranging from strongly disagree to } \\
\text { agree strongly." }\end{array}$ \\
\hline \multicolumn{2}{|l|}{ "Control Variable" } \\
\hline $\begin{array}{l}\text { "AGE = Age of female } \\
\text { entrepreneurs." }\end{array}$ & $\begin{array}{l}\text { "We measured firm age as the number of years the firm has been in operation Firm } \\
\text { age was log-transformed to normalize its distribution and then standardized before } \\
\text { inclusion in the research model." }\end{array}$ \\
\hline $\begin{array}{c}\text { "EDU= Education Level } \\
\text { of entrepreneurs." }\end{array}$ & $\begin{array}{l}\text { "We captured education as any female microenterprise owner who has received at } \\
\text { least up to Junior High School training. We capture this as } 1 \text { Yes if female micro- } \\
\text { entrepreneurs have at least a Junior High School training and } 0 \text { No otherwise." }\end{array}$ \\
\hline "LOC = Location" & $\begin{array}{l}\text { "Firms were selected only from suburbs of Accra (Dome, Ordokor and Circle). } \\
\text { Location information was used to test whether it affects relationships between } \\
\text { microfinance services and family cohesion. We capture this as } 1 \text { Yes if female } \\
\text { micro-entrepreneurs have their businesses operating in each of these locations and } \\
0 \text { No otherwise." }\end{array}$ \\
\hline
\end{tabular}


Family cohesion is the primary dependent variable $(\mathrm{COH}) . \mathrm{COH}$ is assessed for spousal discrepancies, polygyny and alleged disrespect of female household chores. The alpha score for Cronbach was 0.77, which was still inside the reliability threshold (Hair et al. 2006). The principal independent variable in this analysis is indeed MFS. Four items calculate MFS on the five-point scale of Likert. "A 5-point (1) Likert scale strongly disagree and (5) strongly agreed" with each defendant's answer on the advantages of the use of each of these services.

The "Cronbach alpha of 0.78 " reveals a more significant consistency coefficient (Adomako et al., 2016). Besides, in each of the four (4) MFSs given as separate independent factors, different individual dummy variables have been made. The research accounted for the education, place, age, and size, as a result of Karlan and Valdivia's (2011) and (Usman, 2015) past research has been shown toward having intra-relationship influences (Karlan and Valdivia, 2011; Usman 2015). Table 2 below offers comprehensive descriptions of all variables used in the model.

\subsection{Research Model}

The research has "moderated hierarchical regression analysis" to quantify the connections among women's business microfinance performance ("empowerment") and weak family cohesion in recipient societies after previous research "(Adomako et al., 2016; Adomako and Danso, 2014)".

The methodology of this research was to build an integrated framework to evaluate the moderating effect education has had on the MFI services' performance on "women's empowerment and family cohesion." This research followed the methods of these prior business researches and parallel (Cadogan et al. 2006).

The information for multi-collinearity, heteroscedasticity and serial correlation was measured to evaluate the robustness of the model. For both dependent variables, the correlation matrix indicated that neither of the factors had coefficients higher than 0.87 or 0.97 , which were compatible with the Research findings. Models (1) and (2) have been tested for heteroscedasticity and seriality using a robust standard error.

$$
\begin{aligned}
& C O H=B_{-} O+\beta_{-} 1 Z+\beta_{-} Z Z+\varepsilon
\end{aligned}
$$

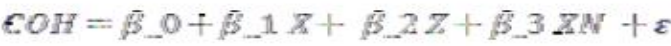

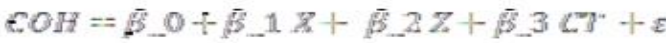

\subsection{Data Analysis Tools}

The data collected will be analyzed through the SPSS 24.0; the linear regression model will be applied for analysis purposes so that the maximum accuracy and validity are secured. The results obtained will be compared with each other.

\section{Results and discussions}

\subsection{Results}

The findings of the matrix of correlations contained in Table 3 demonstrate a significant and favourable association $(0.588, \mathrm{p}<0.01)$ among "poor family cohesion" $(\mathrm{COH})$ and a productive utilize by women of the "MFS" system. Bad cohesion of the family and "FIRMSIZE" are important and completely linked respectively " $(0.630, p<0.01)$ and $(0.195, p<0.05)$ ". The control variables also showed a desirable association among age (age) and firm size $(0.113, p<01)$ (FIRMSIZE). Neither of these factors had a coefficient higher than the 0.87 or 0.97 threshold, such as field (2005) indicated. Their participation in the "multiple regression analysis" however does not establish the multi-linearity issue. 
Is Women Empowerment a Zero-Sum Game? Unintended Consequences of Microfinance for Women's Empowerment in Pakistan

\begin{tabular}{|c|c|c|c|c|c|c|}
\hline \multicolumn{7}{|c|}{ Table 3 Correlation Matrix } \\
\hline COH & COH & MFS & AGE & EDU & LOCATION & FIRMSIZE \\
\hline MFS & 1.000 & & & & & \\
\hline AGE & $0.588^{\star \star \star}$ & 1.000 & & & & \\
\hline EDU & 0.024 & -0.020 & 1.000 & & & \\
\hline LOCATION & $0.630^{\star \star *}$ & -0.053 & 0.074 & 1.000 & & \\
\hline FIRMSIZE & $0.195^{\star *}$ & -0.035 & $0.113^{*}$ & 0.039 & 0.097 & 1.000 \\
\hline
\end{tabular}

Table 4. Regression Analysis for Microfinance Relationship with poor family cohesion

\begin{tabular}{|c|c|c|}
\hline & (1) & (2) \\
\hline VARIABLES & $\mathrm{COH}$ & $\mathrm{COH}$ \\
\hline \multirow[t]{2}{*}{ MFS } & $35.54^{\star * *}$ & $23.41^{\star * *}$ \\
\hline & $(7.90)$ & (6.44) \\
\hline \multirow[t]{2}{*}{ AGE } & 0.0354 & 0.0238 \\
\hline & $(0.98)$ & $(0.74)$ \\
\hline \multirow[t]{2}{*}{ MFS * EDU } & & $0.812^{\star \star *}$ \\
\hline & & (4.71) \\
\hline \multirow[t]{2}{*}{ EDU } & $-0.694^{\star * *}$ & $-2.895^{\star * *}$ \\
\hline & $(-9.35)$ & $(-5.94)$ \\
\hline \multirow[t]{2}{*}{ LOCATION } & 1.076 & $1.815^{\star * *}$ \\
\hline & $(1.26)$ & (2.61) \\
\hline \multirow[t]{2}{*}{ FIRMSIZ } & $-0.701^{\star \star \star}$ & $-0.793^{\star * *}$ \\
\hline & $(-7.19)$ & $(-9.43)$ \\
\hline \multirow[t]{2}{*}{ CONSTANT } & $-47.48^{\star \star \star}$ & $-15.95^{\star}$ \\
\hline & $(-4.70)$ & $(-1.85)$ \\
\hline OBSERVATIONS & 260 & 260 \\
\hline R-SQUARED & 0.689 & 0.791 \\
\hline
\end{tabular}

Table 4 shows the results of the evaluation of "poor family cohesion" (COH) as well as an operational need for "microfinance services (MFS)" by females. The table also shows that education has a moderating effect on the relations among microfinance programs and poor family cohesion. The Model 1 results indicated a positive and important (35.54, p<0.01) association in MFS with $\mathrm{COH}$, which suggested that women may have low family cohesion with the use of MFI services (COH). This analysis confirms the first hypothesis $(\mathrm{H} 1)$ and is similar to current literature on women entrepreneurs' development and growth (Chimthanawala et al., 2015). 
Table 5 Individual effects of Microfinance services on poor family cohesion.

\begin{tabular}{|c|c|c|c|}
\hline & (1) & (2) & (3) \\
\hline & $\mathrm{COH}$ & $\mathrm{COH}$ & $\mathrm{COH}$ \\
\hline & & & $0.803^{\star * \star}$ \\
\hline & $(4.88)$ & (5.96) & $(9.22)$ \\
\hline \multirow[t]{2}{*}{ CREDIT } & $0.439^{* * *}$ & $0.518^{* * *}$ & $0.763^{\star \star \star}$ \\
\hline & $(4.84)$ & $(6.24)$ & $(9.22)$ \\
\hline \multirow[t]{2}{*}{ SAVINGS } & & & $0.827^{\star * \star}$ \\
\hline & & & (12.49) \\
\hline \multirow[t]{2}{*}{ SOCIAL CAPITAL } & & & $0.765^{\star * *}$ \\
\hline & & & $(9.52)$ \\
\hline \multirow[t]{2}{*}{ TRAINING X CREDIT } & & $0.395^{\star * *}$ & 0.0230 \\
\hline & & $(6.90)$ & $(0.55)$ \\
\hline \multirow[t]{2}{*}{ EDU } & $-0.183^{* * *}$ & $-0.327^{* * *}$ & $-0.775^{\star \star \star}$ \\
\hline & $(-3.10)$ & $(-5.38)$ & $(-11.25)$ \\
\hline \multirow[t]{2}{*}{ FIRMSIZ } & -0.0841 & $-0.291^{*}$ & $-0.764^{* * *}$ \\
\hline & $(-0.46)$ & $(-1.80)$ & $(-9.07)$ \\
\hline \multirow[t]{2}{*}{ LOCATION } & 0.426 & 0.501 & $1.260^{*}$ \\
\hline & $(0.27)$ & $(0.36)$ & $(1.95)$ \\
\hline \multirow[t]{2}{*}{ AGE } & -0.0452 & -0.0313 & 0.0452 \\
\hline & $(-0.73)$ & $(-0.54)$ & $(1.27)$ \\
\hline \multirow[t]{2}{*}{ CONSTANT } & $19.10^{\star \star \star}$ & $18.05^{\star \star \star}$ & 1.136 \\
\hline & $(6.37)$ & $(6.04)$ & $(0.97)$ \\
\hline OBSERVATIONS & 260 & 260 & 260 \\
\hline R-SQUARED & 0.1542 & 0.2942 & 0.8045 \\
\hline
\end{tabular}

The research revealed that the correlation between women's education levels and low familial cohesion was significantly adverse $(0.694 \mathrm{p}<0.01)$ with control variables. These findings indicate that more professional women are enabled to reduce their share of poor cohesion by supporting the second hypothesis $(\mathrm{H} 2)$ and therefore complies with the results of their students (Samarakoon and Parinduri, 2015) as the mean level of education has had a significant impact on gender entrepreneurial characteristics in middle-income areas. The investigation revealed that FIRSICE has $\mathrm{COH}$ and was significantly negative $(0.701, p<0.01)$ correlated to $\mathrm{COH}$. This is in line with the outcomes of "Bonomo et al. (2015 and Nyakuma et al. (2016) Damijan et al. (2015), which use these tools to minimize poor cohesion incentives in family businesses because big businesses have a huge amount of money. However, there was no important correlation between age (AGE), position (LOC) and $\mathrm{COH}$ in the sample.

In Table 5 (Model 2), "although the study suggested the moderating effect of education on the association among poor cohesion in family life and microfinance services (MFS). It is argued that entrepreneurial learning helps women to optimize the MFI's services and is much more prominent among highly educated women and positive family cohesion." Following the second hypothesis, the relationship among "poor family cohesion" (COH) and microfinance services (MFS) was identified as crucial and optimistic $(0.812, \mathrm{p}<0.01)$, to moderate the capacity-building relationship.

The significant relation among "poor family cohesion" $(\mathrm{COH})$ and the microfinance (MFs) services $(23.41, p<0.01)$, which is associated with validation of Model 1 , has also been found to be substantially positive. The control variables show that education and corporate size are adverse $(2.895, p<0.01$; 
0.793, $p<0.01)$. Furthermore, the position was considered strongly favourable in Model $2(1.815, p<$ 0.05). The analysis found no meaningful correlation between AGE and $\mathrm{COH}$, indeed.

The four different elements of institutional microfinance services were broken down in enhancing the robustness of the findings.

\subsection{Discussion}

Micro-finance has been identified to foster women's entrepreneurship in Pakistan. Female "empowerment" as a critical driver for MFIs that meet female customers is generally suggested. The results of this research nevertheless indicate a revolutionary tradition of segregation as the result of the accessibility of a micro-finance mechanism (Mazumder and Wencong, 2015; Siwale and Ritchie, 2012).

Women's performance in microfinance often destabilizes family control and generates tension because household roles have been forgotten in mind. This is because women spend more time on their company rather than on their homework. The male spouses feel so threatened by independent female decisions, leading to disputes with their families. In addition, men's conventional position is called into question, and via a second marriage or divorce, they will find an acceptable method to reclaim the power.

"Silverberg (2014 and Stam, Meier zu Selhausen (2014) noticed that while microfinance encourages women to be more self-employed, it may promote domestic violence conflict and robbery in traditional cultures. These are comparable implications. In addition, those findings are in line with Islam's and Pakrashi's (2014) and Olowu's (2011) claims that MFIs concentrating on microfinance lending, coaching and "empowerment" education appear to neglect wider social circumstances and the bad impacts correlated with this. The strategy to loans and associated stress from the microfinance team led to fighting for control between relatives and tribes "(Ali, 2014; Ashta et al., 2015; Mahoney, 2014)." The results indicate that child labour is enhanced in children working for microenterprises and education attainment decreased in several situations. But the negative consequences for girls are much more marked than for boys.

According to existing research on microfinance, the findings of this study show the level of education, size of the organization, and cohesion of the family. There seems to be a clear correlation between education level and borrower loan advantages in Pakistan. Karlan and Valdivia (2011) research education, improving micro-business management preparation and positively affecting cohesion within the family. In the meantime, this research confirms that women micro-finance customers are vulnerable to the severe effects of poor family stability in Pakistan with a lower educational level. Those with a higher academic degree are relatively strong. Data from Bonomo et al. (2015 and Damijan et al. (2015) has demonstrated that bigger microenterprises have a higher capital benefit to minimize family cohesion events.

\section{Conclusion}

The effect of microfinance on successful business, "empowerment" of women and family wellbeing in Pakistan have been studied in this research. This study is an essential step in developing even more productive "empowerment" measures via microfinance for women while disturbing the solidarity of families. The research question microfinance results and concludes that inevitable negative consequences, including marital conflicts, heterosexual monogamy and the lack of female roles observed in the family, have to be considered in the assessments. Microfinance allows women to escape poverty and boost growth outlook potentially.

Although the study demonstrates that women are frequently influenced by or compounded by economic "empowerment", heterosexual monogamy, family disputes, and detrimental effects on young girls' education and wellbeing, they defuse microfinance's advantages. Therefore, this research's main consequence is that the entire family must be directed until the credit facility is authorized by mutual ownership and shared decision making. 
In order to attain the intended result, the study proposes academics, NGOs, credit managers, policymakers and emerging sector stakeholders to carry out more thorough evaluations of microfinance's effect on women's wellbeing.

\subsection{Limitations of the Study}

This study's primary limitation is that Pakistani female microfinance borrowers are the only ones to know the data mentioned earlier. As a consequence, the context of this microfinance investigation must be expanded to future research. Maybe a broader sampling with a cross-country or cultural background captures the unforeseen effects of female microfinance operations. The use of a longitudinal sample can improve the specific characteristics of the association studied because of its transversal structure.

\section{Referencias}

1. Adomako, S. and Danso, A. (2014), "Regulatory environment, environmental dynamism, political ties, and performance", Journal of Small Business and Enterprise Development, Vol. 21 No. 2, pp. 212-230.

2. Adomako, S., Danso, A. and Ofori Damoah, J. (2016), "The moderating influence of financial literacy on the relationship between access to finance and firm growth in Ghana", Venture Capital, Vol. 18 No. 1, pp. 43-61.

3. Aggarwal, R., Goodell, J.W. and Selleck, L.J. (2015), "Lending to women in microfinance: Role of social trust", International Business Review, Elsevier Ltd, Vol. 24 No. 1, pp. 55-65.

4. Agyei, Y.A., Kumi, E. and Yeboah, T. (2016), "Is better to be a kayayei than to be unemployed: reflecting on the role of head portering in ghana???s informal economy", GeoJournal, Vol. 81 No. 2, pp. 293-318.

5. Aísa, M.G. (2014), Conditional Cash Transfers and Intimate Partner Violence among Mexican Couples: The Impact of Oportunidades on Psychological Abuse Prevalence.

6. Akyeampong, E. and Obeng, P. (1995), "Spirituality, Gender, and Power in Asante History", The International Journal of African Historical Studies, Vol. 28 No. 3, pp. 481-508.

7. Alabi, J., Alabi, G. and Ahiawodzi, A. (2007), "Effects of " susu "' a traditional micro finance mechanism on organized and unorganized micro and small enterprises ( MSEs ) in Ghana", African Journal of Business Management, Vol. 1 No. 8, pp. 201-208.

8. AlDajani, H. and Marlow, S. (2013), "“empowerment" a nd entrepreneurship: A theoretical framework", International Journal of Entrepreneurial Behaviour and Research, Vol. 19 No. 5, pp. 503524.

9. Ali, H.M.A. (2014), "Blaming the poor and legitimizing coercive loan recovery strategies: Unveiling the dark side of NGO practices in bangladesh", Anthropologica, Vol. 56 No. 1, pp. 177-191.

10.Annim, S.K. and Alnaa, S.E. (2013), "Access to microfinance by rural women: Implications for poverty reduction in rural households in Ghana", Research in Applied Economics, Vol. 5 No. 2, pp. 19-41.

11.Ashta, A., Khan, S. and Otto, P. (2015), "Does microfinance cause or reduce suicides? Policy recommendations for reducing borrower stress", Strategic Change, Vol. 24 No. 2, pp. 165-190.

12.Augsburg, B., Haas, R. De, Harmgart, H. and Meghir, C. (2012), Microfinance, Poverty and Education.

13.Awumbila, M. (2006), "Gender equality and poverty in Ghana: Implications for poverty reduction strategies", GeoJournal, Vol. 67 No. 2, pp. 149-161.

14.Baiyegunhi, L.J.S. (2014), "Social capital effects on rural household poverty in Msinga, KwaZuluNatal, South Africa", Agrekon, Vol. 53 No. 2, pp. 47-64.

15.Banerjee, A., Duflo, E., Glennester, R.G. and Kinnan, C. (2013), "The miracle of microfinance? Evidence from a randomized evaluation", MIT Department of Economics Working Paper No. 13-09, Vol. 7 No. 1, pp. 1-6. 
16.Basnet, N. (2015), "Reviewing the child labour debates through Kamalahari system in Nepal", South Asian Journal of Multidisciplinary Studies, Vol. 1 No. 5.

17.Bawa, S. and Sanyare, F. (2013), "Women's participation and representation in politics: perspectives from Ghana", International Journal of Public Administration, Vol. 36 No. 4, pp. 282291.

18.Beaman, L., Duflo, E., Pande, R. and Topalova, P. (2012), "Female leadership raises aspirations and educational attainment for girls: A policy experiment in India", Science, Vol. 335 No. 6068, pp. 582586.

19.Bernier, Q. and MeinzenDick, R. (2014), "Resilienc e and social capital”, 2020 Conference, No. May, p. 26.

20.Blackden, C.M., Wodon, Q. and Shetty, S. (2006), "Gender, time use, and poverty in Sub Saharan Africa: Foreword", World Bank Working Paper, No. 73, available at:https://doi.org/10.1596/9780821365618.

21.Blattman, C., Green, E., Annan, J., Jamison, J., Aryemo, F., Carlson, N., Emeriau, M., et al.

22. "Building Women's Economic and Social "empowerment" Through Enterprise, (2013), An Experimental Assessment of the Women's Income Generating Support (WINGS) Program in Uganda", No. 1.

23.Bonomo, M., Brito, R.D. and Martins, B. (2015), "The after crisis governmentdriven credit expansion in Brazil: A firm level analysis", Journal of International Money and Finance, Vol. 55, pp. 111-134.

24.Cadogan, J.W., Cui, C.C., Morgan, R.E. and Story, V.M. (2006), "Factors facilitating and impeding the development of export marketoriented behavior: A study of Hong Kong manufacturing exporters", Industrial Marketing Management, Vol. 35 No. 5, pp. 634- 647.

25.Carullo, G., Castiglione, A., De Santis, A. and Palmeri, F. (2015), "A triadic closure and homophilybased recommendation system for online so cial networks", World Wide Web, Vol. 18 No. 6, pp. 1-23.

26.Chimthanawala, S.M.A., Naidu, K. and Shah, N. V. (2015), "Development and growth of women entrepreneurship of India", International Conference on Technology and Business Management, pp. 320-324.

27.Damijan, J.P., Kostevc, Č. and Polanec, S. (2015), “Access to finance, exporting and a non monotonic firm expansion", Empirica, Vol. 42 No. 1, pp. 131-155.

28.Darlington, P.S. and Mulvaney, B.M. (2014), Women, Power, and Ethnicity:working toward Reciprocal "empowerment", Routledge.

29.Field, A. (2005) Reliability analysis. In: Field, A., Ed., Discovering Statistics Using spss. 2nd Edition, Sage, London.

30.Falb, K.L., Annan, J., King, E., Hopkins, J., Kpebo, D. and Gupta, J. (2014), “Gender norms, poverty and armed conflict in Cote D'lvoire: Engaging men in women's social and economic "empowerment" programming", Health Education Research, Vol. 29 No. 6, pp. 1015-1027.

31.Frey, C.B. and Osborne, M.A. (2015), "The future of employment: How susceptible are jobs to computerization?", Technological Forecasting and Social Change, Vol. 114 No. 1, pp. 254-280.

32.Friggeri, A., Chelius, G. and Fleury, E. (2011), "Triangles to capture social cohesion", Proceedings 2011 IEEE International Conference on Privacy, Security, Risk and Trust and IEEE International Conference on Social Computing, PASSAT/SocialCom 2011, No. July, pp. 257-265.

33.Fuligni, A.J. and Tsai, K.M. (2015), "Developmental Flexibility in the Age of Globalization: Autonomy and Identity Development Among Immigrant Adolescents", Annual Review of Psychology, Vol. 66 No. 1, pp. 411-431.

34.Ganle, J.K., Afriyie, K. and Segbefia, A.Y. (2015), "Microcredit: "empowerment" and dis"empowerment" of rural women in Ghana", World Development, Vol. 66, pp. 335-345.

35.GarcíaRodríguez, F.J. (2012), "New methods in univ ersity entrepreneurship education: A multidisciplinary teams approach", Creative Education, Vol. 3 No. October, pp. 878-883.

36.Gibson, M.A. and Mace, R. (2007), "Polygyny, reproductive success and child health in rural Ethiopia: why marry a married man?", Journal of Biosocial Science, Vol. 39 No. 2, p. 287. 
37.Gobezie, G. (2009), "Sustainable rural finance: Prospects, challenges and implications", International NGO Journal, Vol. 4, pp. 12-26.

38.Goltz, S., Buche, M.W. and Pathak, S. (2015), "Political "empowerment", rule of law, and women's entry into entrepreneurship", Journal of Small Business Management, Vol. 53 No. 3, pp. 605-626.

39.Hair, J.F., Black, W., Babin, B., Anderson, R. and Tatham, R. (2006), Multivariate Data Analysis, Pearson Prentice Hall., Vol. 6, available at:https://doi.org/10.1080/19447013008687143.

40.Halkias, D., Nwajiuba, C., Harkiolakis, N. and Caracatsanis, S.M. (2011), "Challenges facing women entrepreneurs in Nigeria", Management Research Review, Vol. 34 No. 2, pp. 221-235.

41.Hughes, C., Bolis, M., Fries, R. and Finigan, S. (2015), "Women's economic inequality and domestic violence: exploring the links and empowering women", Gender and Development, Taylor \& Francis, Vol. 23 No. 2, pp. 279-297.

42.Islam, A. and Pakrashi, D. (n.d.). "DEPARTMENT OF ECONOMICS The Microcredit Puzzle : Labour Supply Behaviour of Rural Households in microcredit in the intra household and intersectoral distribution of labour supply. The data also en microcredit on labour supply are not symmetrical across".

43.Jaggers, J.W., Church, W.T., Tomek, S., Hooper, L.M., Bolland, K.A. and Bolland, J.M. (2015), "Adolescent development as a determinant of family cohesion: A longitudinal analysis of adolescents in the mobile youth survey", Journal of Child and Family Studies, Springer US, Vol. 24 No. 6, pp. 1625-1637.

44.Jalbert, S.E. (2000), Women Entrepreneurs in the Global Economy.

45.Jin, B. (2015), "Family Cohesion and Child Functioning Among South Korean Immigrants in the Us: the Mediating Role of Korean Parent Child Closeness and the Moderating Role of", No. May.

46.Khan, Nohman, Muhammad Imran Qureshi, Ishamuddin Mustapha, Sobia Irum, and Rai Naveed Arshad. 2020. "A Systematic Literature Review Paper on Online Medical Mobile Applications in Malaysia." International Journal of Online and Biomedical Engineering 16(1):63-82.

47.Karlan, D. and Valdivia, M. (2011), "Teaching entrepreneurship: Impact of business training on microfinance clients and institutions", Review of Economics and Statistics, Vol. 93 No. 2, pp. 510527.

48.Klugman, J., Hanmer, L., Twigg, S., Hassan, T., McClearySills, J. and Santamaria, J. (2014), Voice and Agency: Empowering Women and Girls for Shared Prosperity.

49.Kulkarni, V.S. (2011), Women's "empowerment" and Microfinance: An Asian Perspective Study, available at:https://doi.org/ISBN 9789290722809.

50.Lang, K. (2011), Poverty and Discrimination, Princeton University Press.

51.Leatherman, S., Dunford, C., Metcalfe, M., Reinsch, M., Gash, M. and Gray, B. (2011), "Integrating Microfinance and Health Benefits , Challenges and Reflections for Moving Forward", 2011 Global Microcredit Summit.

52.Lindvert, M. (2006), Sustainable Development Work and Microfinance- a Case Study of How ECLOF Ghana Is Working towards Financial Sustainability, Mid Sweden University.

53. Mahoney, K. (2014), "Microcredit: A model of "empowerment" for women? Dissenting Voices, Vol. 3 No. 1, pp6.

54.Maldonado, J.H. and GonzálezVega, C. (2008), "Impa ct of microfinance on schooling: Evidence from poor rural households in Bolivia", World Development, Vol. 36 No. 11, pp. 2440-2455.

55.Mayoux, L. (2001), "Tackling the down side: Social capital, women's "empowerment" and microfinance in Cameroon", Development and Change, Vol. 32, pp. 435-464.

56.Mazumder, M.S.U. and Wencong, L. (2015), "Does microfinance impact on rural "empowerment" in Bangladesh? Differences between Governmental and Non Governmental microfinance programs", Sustainable Development, Vol. 23 No. March, pp. 135-152.

57.Meth, P. (2013), "Millennium development goals and urban informal settlements: unintended consequences", International Development Planning Review, Vol. 35 No. 1, pp. v-xiii.

58.Milanov, H., Justo, R. and Bradley, S.W. (2015), "Making the most of group relationships: The role of gender and boundary effects in microcredit groups", Journal of Business Venturing, Elsevier Inc., Vol. 30 No. 6 , pp. 822-838. 
59. Misztal, B. (1996), Trust in Modern Societies: The Search for the Bases of Social Order, John Wiley.

60.Nyakuma, D.D., Jaleel, A., Shittu, K., Ojobo, H. and Ivase, T.J. (2016), "Challenges of adopting information and communications technology by small and medium enterprises in Nigeria", Journal of Multidisciplinary Engineering Science and Technology, Vol. 3 No. 1, pp. 3766-3776.

61.Ogato, S. (2013), "The quest for gender equality and womens "empowerment" in least developed countries: Policy and strategy implications for achieving millennium development goals in Ethiopia", International Journal of Sociology and Anthropology, Vol. 5 No. 9, pp. 358-372.

62. Olowu, D. (2011), "Mainstreaming women, equating men: Charting an inclusionary approach to transformative development in the African decade for women", Law, Democracy \& Development, Vol. 15, pp. 1-22.

63.Opsahl, T. (2013), "Triadic closure in twomode net works: Redefining the global and local clustering coefficients", Social Networks, Vol. 35 No. 2, pp. 159-167.

64.Peterson, N.A. and Hughey, J. (2004), "Social cohesion and intrapersonal "empowerment": Gender as moderator", Health Education Research, Vol. 19 No. 5, pp. 533-542.

65.Raven, P. and Le, Q. V. (2015). "Teaching business skills to women: Impact of business training on women's microenterprise owners in Vietnam", International Journal of Entrepreneurial Behavior and Research, Vol. 21 No. 4, 622641.

66.Salia, P.J. (2014), "The effect of microcredit on the household welfare (Empirical Evidences from women microentrepreneurs in Tanzania)", International Journal of Academic Research in Business and Social Sciences, Vol. 4 No. 5, pp. 259-272.

67.Samarakoon, S. and Parinduri, R.A. (2015), "Does education empower women? Evidence from Indonesia", World Development, Vol. 66, pp. 428-442.

68.Schindler, K. (2010), "Credit for what? Informal credit as a coping strategy of market women in northern Ghana", Journal of Development Studies, Vol. 46 No. 2, pp. 234-253.

69.Seidu, A. and Bambangi, S. (2006), "Microcredit po verty alleviation: An analysis of the performance of women in microcredit activities in the Kassena Nankana district of Ghana", Ghana Journal of Deevlopment Studies, Vol. 3 No. 2, pp. 41-56.

70.Silverberg, S. (2014), "One size does not fit all: A study of microfinance practices in Peru", Undercurrent, Vol. 10 No. 2, pp. 45-53.

71.Siwale, J.N. and Ritchie, J. (2012), "Disclosing the loan officer's role in microfinance development", International Small Business Journal, Vol. 30 No. 4, pp. 432-450.

72.Skovdal, M. (2010), "Community relations and child led microfinance: a case study of caregiving children in Kenya", AIDS Care, Vol. 22 No. sup2, pp. 1652-1661.

73.Srivinisa, A.T. and Shivanna, B.K. (2014), "Microf inance and women "empowerment" in Old Town Yalahanka, Banglore North Taluk", International Journal of Retailing \& Rural Business Perspectives, Vol. 3 No. 4, p. 1319.

74.Stam, E. and Meier zu Selhausen, F. (2014), Husbands and Wives. The Powers and Perils of Participation in a Microfinance Cooperative for Female Entrepreneurs.

75.Stromquist, N.P. (2015), "Women's wmpowerment and education: Linking knowledge to transformative action", European Journal of Education, Vol. 50 No. 3, pp. 307-324.

76.Sveiby, K., Gripenberg, P., Segercrantz, B., Eriksson, A. and Aminoff, A. (2009), "Unintended and undesirable consequences of innovation", XX ISPIM Conference The Future of Innovation, No. June 2015, pp. 1-16.

77.Tamale, S. (2004), "Gender trauma in Africa: enhancing women's links to resources", Journal of African Law, Vol. 48 No. 1, pp. 50-61.

78. United Nations. (2009), Rethinking Poverty: Report on the World Social Situation 2010, The Effects of Brief Mindfulness Intervention on Acute Pain Experience: An Examination of Individual Difference, Vol. 1, available at:https://doi.org/10.1017/CBO9781107415324.004.

79. United nation, 2010. 2010 report on the world social situation. Department of economics and social affairs, social inclusion. New York.

80.United nation, 2015. United nation sustainable development summit 2015. 25-27 September 2015, New York. 
81.Usman, 2015. Determining the Entrepreneurial Intentions of Youth/Generation Z - A Study of Youth Intent towards Entrepreneurship. Department of business studies. 02 November, 2015.

82.Zeidan S and Bahrami S (2011) Women entrepreneurship in GCC: A framework to address the challenges and promote participation in a regional context. International Journal of Business and Social Science 2(14): 100-107. 